\title{
Identification Of Risk Events And Risk Agents In Goods Hoarding At The Port Using Fishbone Diagram (Case in the loading and unloading company)
}

\author{
Aditya Maharani ${ }^{1}$, LatofSyeikhur Rabbani ${ }^{2}$ \\ ${ }^{1,2}$ Shipbuilding Institute of Polytechnic Surabaya \\ E-mail : maharani@ppns.ac.id
}

\begin{abstract}
PT. $X$ is a loading and unloading company (Perusahaan BongkarMuat/ PBM) which operates in the Port of Tanjung Perak, Surabaya. In 2018, the PBM experienced a hoarding of 65,698 tons of wirerod so the company had to issue a hoarding rate of $R p$. 147,820,500. The fishbone diagram method is used to look for risk events and risk agents. From three main problems of goods hoarding, it is obtained the results of identification of risk events and risk agents, there are 17 risk events and 30 risk agents identified as triggers for the hoarding of goods at the port.
\end{abstract}

Key word: identification of risks, risk events; risk agents; goods hoarding; fishbone diagram.

\section{INTRODUCTION}

Geographically, Indonesia is located between two oceans, the Pacific Ocean and the Indian Ocean, and connects the Asian and Australian continents. Indonesia has more than 17 thousand islands, with a coastline of more than $99,000 \mathrm{~km}$, making Indonesia as the country with the second longest coastline in the world after Canada. Indonesia has a vast sea area, where $2 / 3$ of the country's territory is the sea. Most of Indonesia's territory in the form of the sea, making Indonesia as one of the countries that has great potential in the marine field. [1]

With this area, in 2015 the Jokowi President launched the "Sea Toll". This program aims to connect the major ports in the archipelago. With the relationship between these sea ports, it can create a smooth distribution of goods to remote areas. In addition to that, the distribution of Logistics prices for each item in all regions of Indonesia. [2]
To achieve this goal many facilities and services must be provided. One of the improved seaport services is the service of a loading and unloading company (PBM).

Loading and Unloading Companies $(\mathrm{PBM})$, which are "companies that specifically work in the field of loading and unloading of goods to and from ships both from and to the first line warehouse of or directly to transportation fleets. The process of loading and unloading activities consists of three types, including stevedoring, the activity of unloading goods from the hatch to the dock or vice versa;cargodoring, the activity of moving goods from the dock to the warehouse or vice versa; and delivery, the process of sending goods from the pier to the factory owner of the goods". [3]

The Tanjung Perak Port as one of the gateways of Eastern Indonesia, has not been able to keep pace with the rapid economic growth in Indonesia in recent years. These problems also occur at PT. X. In PBM which operates in Tanjung Perak Port, the process of loading and unloading, especially in the delivery of goods from the pier to the factory owner of goods (consignee) experiences several obstacles, which cause goods that have been unloaded from the ship can not be directly delivered. This causes the goods hoarding, causing additional logistical costs to be incurred by PBM.

At PT X, one of the commodities that experienced the most hoarding in 2018 was wirerod of 65,698 tons. As a result of the hoarding of these commodities PBM must issue a hording rate of up to $\mathrm{Rp}$. 147,820,500.00.

PBM also spends money to pay tariffs on other products. So that it will reduce the company's profit. To overcome these problems, it is necessary to identify risk factors (Risk Events) and address the underlying causes of risk (Risk Agent) the 


\section{Tibuana}

Journal of applied Industrial Engineering-University of PGRI Adi Buana

p-ISSN 2622-2027

$e$-ISSN 2622-2035

buildup of goods at the port that occurs during loading and unloading taking place at PT X.

The problem in this research is how to identification of risk events and risk agents arising from the goods hoarding at the port at PT X.

The purpose of this study is to determine the risks events and risks agents arising from goods hoarding at the port at PT X.

\section{RESEARCH METHODOLOGY}

The research methology shown at Figure 1

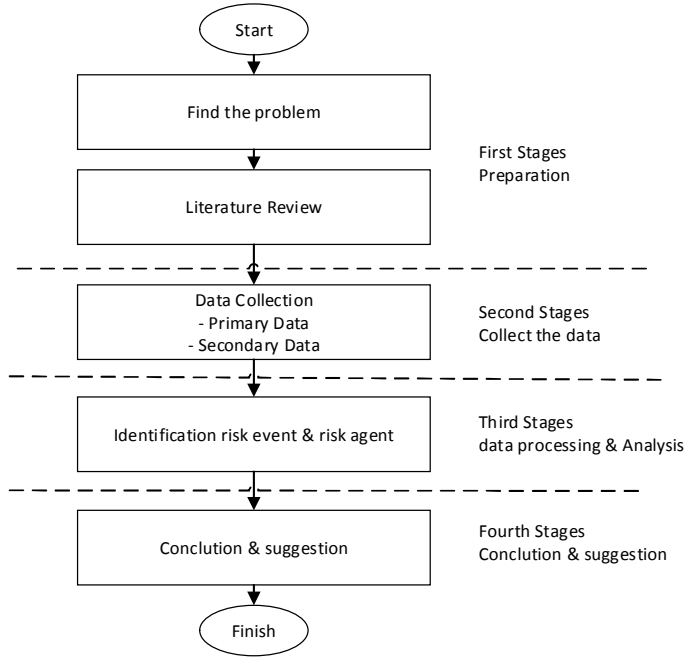

Figure 1. Research Methology

The following are the stages of the methodology in this research.

\section{Stage 1: Preparation}

\section{a. Problem Formulation}

At this stage the researcher identified the problems that exist in PBM in carrying out its business activities. One of the problems encountered was the goods hoarding in Kade or the piling field, thereby increasing the logistics costs that PBM had to bear. This problem identification is used by researchers to determine the formulation of the problem and the determination of research objectives.

b. Literature review

This stage is carried out by collecting literature review in order to obtain references that support the research process. The literature used in research is based on journals, books related to risk management and books related to loading and unloading.

\section{Stage 2: Data Collection}

- Primary data

This stage begins with observations about the process of loading and unloading activities at PBM, especially in the process of delivery from the port to the importing wirerod cargo factory, which consists of the process of handling goods before being sent, when sent and after being sent.

- Secondary Data

Secondary data used in this study is the data accumulation of goods in 2018 for the past 1 year along with data on the goods hoarding.

Stage 3: Data processing and analysis

At this stage a fishbone diagram is made for risk events and risk agents from the results of data collection.

\section{Stage 4: Conclusions and Suggestions}

At this stage a conclusion is drawn according to the problem. While advice is given with the aim to provide recommendations for further research.

\section{RESULT AND DISCUSSION}

\section{A. Loading and Unloading Process}

The process of loading and unloading goods includes 3 processes, i.e

1. Stevedoring means the work of unloading I moving goods from the ship to the dock. In this stevedoring stage, all processes of planning, implementation, and supervision of the movement of goods from the time they are lifted from inside the ship to neatly stacked on trucks or at the docks are the responsibility of the PBM.

2. Cargodooring, means the work of transporting goods from the dock to the stock yard or to the warehouse.

3. Delivery is the process of sending goods from the dock to the factory owner of the goods.

In the process of loading and unloading, the smooth process is the responsibility of all elements involved, ranging from the PBM management, field workers to the independent companies such as surveyors.

The following is a description of the stages of loading and unloading of goods at PT X. 
1. The initial stage when the ship arrives, which is the process of leaning against a ship assisted by a scout (tug boat) for its parking process.

2. After the ship docked, the next step is the board boarding process. Ship boarding is the process of approving ship documents by the port authority, immigration and syahbandar. These documents are Registry, Tonnage, Safe meaning, Derating, Liferaft, PMK, PSC, WRECK, CLC, Last Port, Load Line, IOPP, IAPP, Sewace, Radio, Construction, Equipment.

3. The next step is the surveyor checks the goods. Surveyor is an independent party chosen by the owner of the goods to check the cargo before being unloaded and to be reported to the owner of the goods

4. After the goods have been checked and declared okay to be unloaded by the surveyors, the next step is the preparation process for demolition by lowering TKBM (loading and unloading labor/ tenagakerjabongkarmuat) to the field and ships, preparing heavy equipment in the form of cranes, and forklifts as well as the hatch opening process.

5. After the preparation is complete, the unloading of goods begins with lifting one by one or more of the hatch to the dock using a crane aid.

6. Clearance status of goods or cargo is declared completed or not, if not then the goods that have been unloaded will be stockpiled or piled in the stacking field. The stockpiled goods will wait for the clearance status to be completed, if the clearance is complete the stockpiled goods can come out of the port and ready to be sent to the factory owner of the goods.

7. If the clearance status of goods has been completed during the unloading process, the goods can be directly transported by truck to be sent to the owner of the goods.

8. The next step is the process of delivery goods to the factory loaded using a fleet of trucks whose shipments have also been arranged by the EMKL and PBM.

9. After the goods truck arrives at the factory, the goods are checked by the factory tally to match the travel documents given by the driver to the goods loaded on the truck.

10.After the goods are checked by the factory tally, trucks can queue the demolition process at the factory. The demolition always takes place in a queue, because the position of the land in the factory is not as large as the port. In addition, due to several factors such as forklift heavy equipment that is less or not as much as there is at the port and various other factors.

11.After passing the queue, the goods loaded on the truck are unloaded with heavy equipment in the form of forklifts and the goods are arranged in the factory in accordance with the goods arrangement layout in each factory owner of the goods.

12. Trucks whose cargo has been unloaded, will return to the port with empty cargo and will load goods back from the port until the unloading goods from the ship are gone because all have been sent to the owner of the goods.

\section{B. Stages Of The Clearance Process}

Stages of the clearance process are divided into 3 stages: the pre clearance stage, the custom clearance stage, and the post clearance stage.

\section{Pre ClearenceStage}

The Pre Clearence Phase is a stage that starts from the time the ship rests, unloading to the owner of the goods submitting an import notification of goods (PIB/pemberitahuanimporbarang) online to the Customs office. The following are the detailed stages of the pre clearance activities:

1. Goods owner submits import documents in the form of Power of Attorney, Bill of Lading, Invoice, Packing List, Insurance, NPWP to the Customs office through EMKL (Sea Cargo Expedition/ Ekspedisimuatankapallaut).

2. Goods Owner makes PIB documents at Customs through the EMKL with an online system.

3. The owner of the goods makes SSPCP (Customs, Excise and Tax Payment/ SuratSetoranPabean, Cukaidan, Pajak). 
4. Repayment of PIB for the process of paying VAT, PPh at the Bank designated by the Customs office.

5. Goods owner takes PIB that has been registered by the bank.

6. Pay the import duty by showing the Bill of Lading and PIB documents to the bank officer appointed by the Customs office.

7. The bank submits the full set of documents to the owner of the goods or importer in hardcopy form.

\section{Custom Clearence Stage}

The custom clearance stage is a stage that starts from the Notification of Imported Goods received by the Customs Office until the issuance of the Notification of Goods (SPPB/

SuratPemberitahuanPengeluaranBarang) issued by Customs. The following are details of the stages of custom clearence activities.

1. The Customs Party matches the similarity of data that has been submitted in the online system.

2. The process of examining goods documents and physical inspection of goods to determine whether goods may leave the port or not. If there is a mismatch of goods that are incompatible with the document of goods that have been submitted to the Customs, the goods are not allowed to leave the port area and the goods will be stacked in the port field until the processing of the incompatible documents is complete.

3. When the goods inspection process has been completed, and the goods have been declared to be in compliance, the Customs Office issues SPPB as approval for the release of goods from the port to the goods owner.

4. Goods may be allowed to exit the port.

\section{Post ClearenceStage}

The post clearence stage is a stage that starts from the SPPB issue until the release of goods from the port or port stacking field. The following are the detailed stages of the post clearence activity.

1. The goods owner or the importer pays the freight costs to EMKL.

2. After making payment, EMKL issues a DO (delivery order) document by exchanging the original Bill of Lading of the owner of the goods to EMKL.

3. The owner of the goods or importer receives 1 sheet of original $\mathrm{D} / \mathrm{O}$ and a copy.

4. The owner of the goods submit D / O documents, Packing List, Invoice, Bill of Lading, PIB, and SPPB to Pelindo.

5. After that Pelindo issues SP2 Note or Notification of Expenditures.

\section{Identification Of Sources Of Risk With Fishbone Diagram}

In the phase of identifying sources of risk, a fishbone diagram is needed to identify and organize the causes that might arise from specific factors and then to separate the root causes. The identification process begins with an interview process with the relevant company, namely about the hoarding of goods. In this study, fishbone is divided into 3 parts of the problem of accumulation of goods that occur in the company (PT X). Among them are delays in the management of goods delivery documents, obstacles in the process of shipping goods and obstacles in the process of receiving goods at the factory.

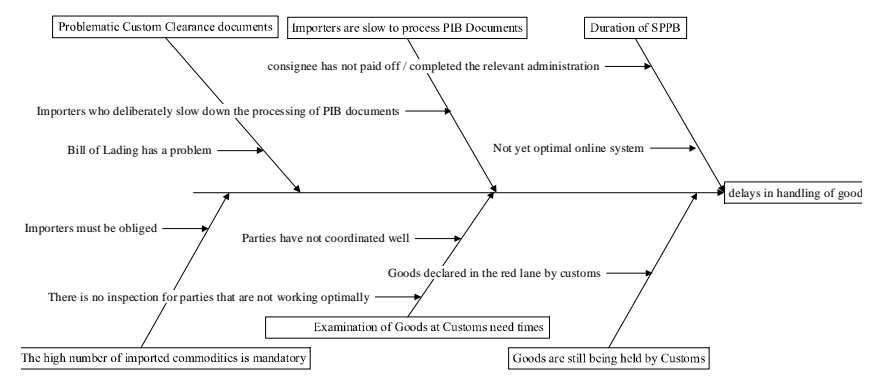

Figure 2. Fishbone diagram for delays in the handling of goods shipping documents

In Figure 2 explains that the root causes of the handling of goods documents have 6 sources of risk and 8 factors causing these sources of risk. The root causes of the process of shipping goods will be illustrated in the fishbone diagram below. 


\section{Tibuana}

$e$-ISSN 2622-2035

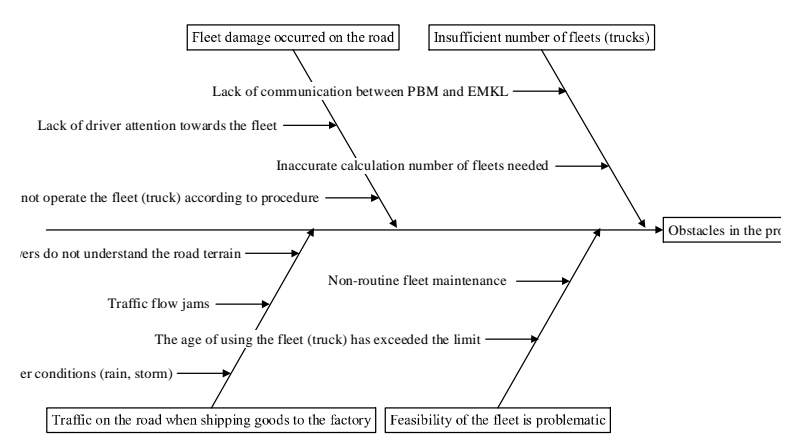

Figure 3. Fishbone diagram for obstacles in the process of shipping goods

In Figure 3 shows that in the process of shipping goods there are 4 sources of risk and 9 causative factors. The next stage analyzes the root problems that occur when the process of receiving goods at the factory, the analysis will be illustrated through the fishbone diagram below.

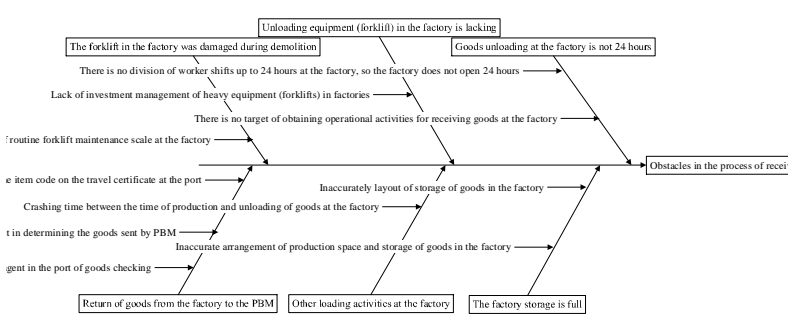

Figure 4. Fishbone diagram for the process of receiving goods at the factory

In Figure 4 shows that in the process of receiving goods at the factory there are 6 sources of risk and 10 factors causing each of these sources of risk. The three root sources of the problem of accumulation of goods that occur at PT. X has been analyzed through the fishbone diagram above.

\section{Identification of Risk Events and Risk Agents.}

The process of identifying risk events and risk agents that result in the goods hording during the process of loading and unloading takes place through an interview and discussion process with the relevant company. The following is a table of risk events and goods accumulation agent.

Table 1: Identification risk events for Goods hoarding in loading and unloading process

\begin{tabular}{|c|l|}
\hline Code & Risk Event \\
\hline E1 & Duration of SPPB (Notification of Goods \\
\hline
\end{tabular}

\begin{tabular}{|c|c|}
\hline & $\begin{array}{l}\text { Expenditure/ } \\
\text { SuratPemberitahuanPengeluaranBarang) Issuance }\end{array}$ \\
\hline E2 & $\begin{array}{l}\text { Importers are slow to process PIB (Notification of } \\
\text { Imported Goods/ PemberitahuanImporBarang) }\end{array}$ \\
\hline E3 & $\begin{array}{l}\text { Problematic Custom Clearance documents that } \\
\text { cause goods not to come out }\end{array}$ \\
\hline E4 & Goods are still being held by Customs \\
\hline E5 & Examination of Goods at Customs need times. \\
\hline E6 & $\begin{array}{l}\text { The high number of imported commodities is } \\
\text { mandatory. }\end{array}$ \\
\hline E7 & Insufficient number of fleets (trucks). \\
\hline E8 & Fleet damage occurred on the road. \\
\hline E9 & $\begin{array}{l}\text { Feasibility of the fleet is problematic, which causes } \\
\text { truck trips to be blocked in speed to get to the } \\
\text { factory on time. }\end{array}$ \\
\hline E10 & $\begin{array}{l}\text { Traffic on the road when shipping goods to the } \\
\text { factory. }\end{array}$ \\
\hline E11 & goodsunloading at the factory is not 24 hours. \\
\hline E12 & $\begin{array}{l}\text { Unloading equipment (forklift) in the factory is } \\
\text { lacking. }\end{array}$ \\
\hline E13 & $\begin{array}{l}\text { The forklift in the factory was damaged during } \\
\text { demolition. }\end{array}$ \\
\hline E14 & The factory storage is full. \\
\hline E15 & Other loading activities at the factory. \\
\hline E16 & Return of goods from the factory to the PBM. \\
\hline E17 & Obstacles beyond control. \\
\hline
\end{tabular}

Source: Observation and Interview Results, 2019.

Table 1 is a table of the results of the identification of risk events in the loading and unloading of goods obtained from the results of the interview. From the results of the interview and analysis through the fishbone diagram, there are 17 risk events for the goods hoarding that occur in the company.

The next step is to identify the risk agents which are trigger factors or causes of the occurrence of risk events. The following is the result of risk agent identification.

Table 2: Identification risk Agent for Goods hoardingin loading and unloading process

\begin{tabular}{|c|c|}
\hline Code & Risk Agent \\
\hline A1 & $\begin{array}{l}\text { The owner of the goods (consignee) has not paid } \\
\text { off / completed the relevant administration. }\end{array}$ \\
\hline A2 & Not yet optimal online system. \\
\hline A3 & $\begin{array}{l}\text { Importers who deliberately slow down the } \\
\text { processing of PIB documents. }\end{array}$ \\
\hline A4 & Bill of Lading has a problem. \\
\hline A5 & Goods declared in the red lane by customs. \\
\hline A6 & Parties have not coordinated well. \\
\hline
\end{tabular}




\section{Tibuana}

Journal of applied Industrial Engineering-University of PGRI Adi Buana

p-ISSN 2622-2027

$e$-ISSN 2622-2035

\begin{tabular}{|c|c|c|}
\hline A7 & $\begin{array}{l}\text { There is no inspection for parties that are not } \\
\text { working optimally. }\end{array}$ & $\begin{array}{l}\text { results of the interview. From the results of } \\
\text { interviews and analysis of the fishbone }\end{array}$ \\
\hline A8 & $51 \%$ Importers must be obliged. & diagram, there are 30 risk agents \\
\hline A9 & Lack of communication between PBM and EMKL. & events. \\
\hline
\end{tabular}

\section{CONCLUSION}

The conclusion of this research is

1. The main problems in the accumulation of goods in PT $X$ are delays in the management of goods shipping documents, obstacles in the process of shipping goods and obstacles in the process of receiving goods at the factory.

2. The results of identification of risk events and risk agents, there are 17 risk events and 30 risk agents identified as triggers for the accumulation of goods at the port.

Suggestions from this research

This research only identifies risk events and risk agents, so that future studies can be assessed severity (impact) on risk events and occurance (level of emergence) on risk agents by distributing questionnaires to the relevant company experts.

\section{REFERENCES}

1. https://geotimes.co.id/opini/refleksiindonesia-sebagai-negara-maritim/

2. https://id.wikipedia.org/wiki/Tol_Laut

3. SK MenteriPerhubungan No. KM. 88/AL.305/Phb-85

4. Geraldin. (2007). Manajemen risiko dan aksi mitigasi untuk mencapai rantai pasok yang robust. Tesis Institute Teknologi Sepuluh Nopember.

5. Hanafi, M. Mamduh. (2009). Manajemen Risiko. Yogyakarta: UPP STIM YKPN

6. Heizerdan Render. (2011). Manajemen Operasi. Edisi Sembilan. Buku Dua. Jakarta: Salemba Empat.

7. Hopkin, P. (2010). Fundamentals of Risk Management. Evaluating and Implementing Effective Risk Management, Kogan Page.

8. Lokobal, A. M. (2014). Manajemen Risiko Pada Perusahaan Jasa Pelaksana Kontruksi Di Provinsi Papua. Jurnal Ilmiah Media Engineering, 109118. 